\title{
Manure application increased denitrifying gene abundance in a drip-irrigated cotton field
}

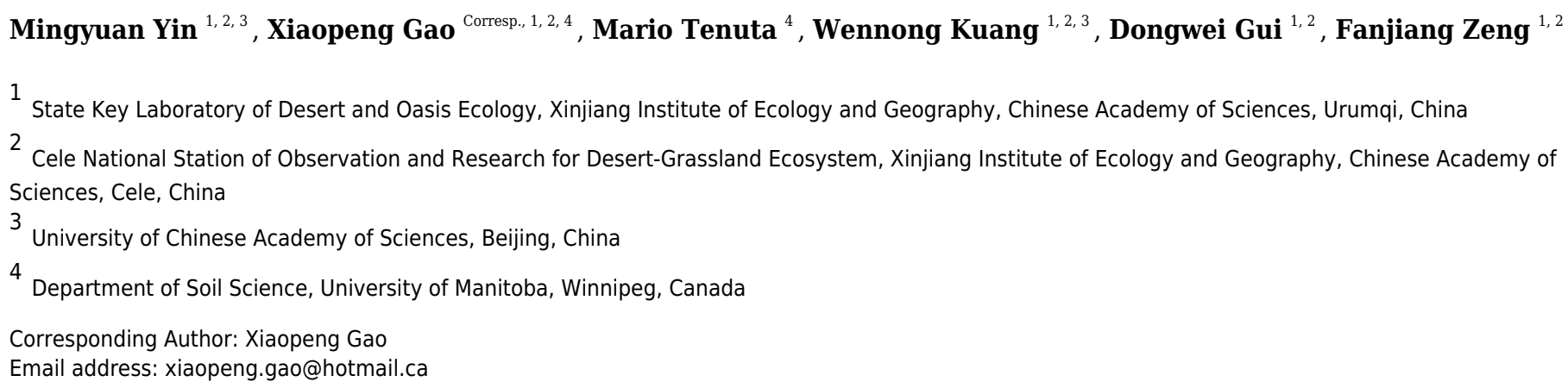

Application of inorganic nitrogen $(\mathrm{N})$ fertilizer and manure can increase nitrous oxide $\left(\mathrm{N}_{2} \mathrm{O}\right)$ emissions. We tested the hypothesis that increase in $\mathrm{N}_{2} \mathrm{O}$ flux from soils amended with manure reflects a change in bacterial community structure and, specifically, an increase in the number of denitrifiers. To test this hypothesis, a field experiment was conducted in a drip-irrigated cotton field in an arid region of northwestern China. Treatments included plots that were not amended (Control), and plots amended with urea (Urea), animal manure (Manure) and a 50/50 mix of urea and manure (U+M). Manure was broadcastincorporated into the soil before seeding while urea was split-applied with drip irrigation (fertigation) over the growing season. The addition treatments did not, as assessed by nextgen sequencing of PCR-amplicons generated from rRNA genes in soil, affect the alpha diversity of bacterial communities but did change the beta diversity. Compared to the Control, the addition of manure ( $\mathrm{U}+\mathrm{M}$ and Manure) significantly increased the abundance of genes associated with nitrate reduction (narG) and denitrfication (nirK and nosZ). Manure addition ( $U+M$ and Manure) did not affect the nitrifying enzyme activity (NEA) of soil but resulted in 39-59 times greater denitrifying enzyme activity (DEA). In contrast, urea application had no impact on the abundances of nitrifier and denitrifier genes, DEA and NEA; likely due to a limitation of C availability. DEA was highly correlated $(r=0.70$ $0.84, P<0.01$ ) with the abundance of genes narG, nirK and nosZ. An increase in the abundance of these functional genes was further correlated with soil $\mathrm{NO}_{3}{ }^{-}$, dissolved organic carbon, total $\mathrm{C}$, and total $\mathrm{N}$ concentrations, and soil C: $\mathrm{N}$ ratio. These results demonstrated a positive relationship between the abundances of denitrifying functional genes (narG, nirK, and nosZ) and denitrification potential, suggesting that manure application increased $\mathrm{N}_{2} \mathrm{O}$ emission by increasing denitrification and the population of 
bacteria that mediated that process. 
1 Manure application increased denitrifying gene abundance in a drip-irrigated

2 cotton field

3 Mingyuan Yin ${ }^{1,2,3}$, Xiaopeng Gao ${ }^{1,2,4}$, Mario Tenuta ${ }^{4}$, Wennong Kuang ${ }^{1,2,3}$, Dongwei Gui ${ }^{1,2}$,

$4 \quad$ Fanjiang Zeng ${ }^{1,2}$

$5{ }^{1}$ State Key Laboratory of Desert and Oasis Ecology, Xinjiang Institute of Ecology and Geography,

6 Chinese Academy of Sciences, Urumqi, 830011, China

$7 \quad{ }^{2}$ Cele National Station of Observation and Research for Desert-Grassland Ecosystem, Xinjiang

8 Institute of Ecology and Geography, Chinese Academy of Sciences, Cele, 848300, China

$9 \quad{ }^{3}$ University of Chinese Academy of Sciences, Beijing, 100049, China

$10{ }^{4}$ Department of Soil Science, University of Manitoba, Winnipeg, MB, R3T 2N2, Canada

12 Corresponding author

13 Xiaopeng Gao,

14 xiaopeng.gao@umanitoba.ca 
15

ABSTRACT

Application of inorganic nitrogen $(\mathrm{N})$ fertilizer and manure can increase nitrous oxide $\left(\mathrm{N}_{2} \mathrm{O}\right)$ emissions. We tested the hypothesis that increase in $\mathrm{N}_{2} \mathrm{O}$ flux from soils amended with manure reflects a change in bacterial community structure and, specifically, an increase in the number of denitrifiers. To test this hypothesis, a field experiment was conducted in a drip-irrigated cotton field in an arid region of northwestern China. Treatments included plots that were not amended (Control), and plots amended with urea (Urea), animal manure (Manure) and a 50/50 mix of urea and manure $(\mathrm{U}+\mathrm{M})$. Manure was broadcast-incorporated into the soil before seeding while urea was split-applied with drip irrigation (fertigation) over the growing season. The addition treatments did not, as assessed by nextgen sequencing of PCR-amplicons generated from rRNA genes in soil, affect the alpha diversity of bacterial communities but did change the beta diversity. Compared to the Control, the addition of manure (U+M and Manure) significantly increased the abundance of genes associated with nitrate reduction ( $\operatorname{nar} G)$ and denitrfication (nirK and nosZ). Manure addition (U+M and Manure) did not affect the nitrifying enzyme activity (NEA) of soil but resulted in 3959 times greater denitrifying enzyme activity (DEA). In contrast, urea application had no impact on the abundances of nitrifier and denitrifier genes, DEA and NEA; likely due to a limitation of C availability. DEA was highly correlated $(r=0.70-0.84, P<0.01)$ with the abundance of genes nar $G, \operatorname{nir} K$ and $n o s Z$. An increase in the abundance of these functional genes was further correlated with soil $\mathrm{NO}_{3}{ }^{-}$, dissolved organic carbon, total $\mathrm{C}$, and total $\mathrm{N}$ concentrations, and soil $\mathrm{C}: \mathrm{N}$ ratio. These results demonstrated a positive relationship between the abundances of denitrifying functional genes (narG, nirK, and nosZ) and denitrification potential, suggesting that manure 
36 application increased $\mathrm{N}_{2} \mathrm{O}$ emission by increasing denitrification and the population of bacteria

37 that mediated that process.

38 Keywords Bacterial community structure, Denitrifier, Denitrifying enzyme activity, Drip

39 irrigation, Functional genes, Manure, Nitrifier 


\section{INTRODUCTION}

Nitrous oxide $\left(\mathrm{N}_{2} \mathrm{O}\right)$ accounts for nearly $8 \%$ of the warming impact of anthropogenic activities and contributes to the depletion of ozone in the stratosphere (Ravishankara, Daniel \& Portmann, 2009). The $\mathrm{N}_{2} \mathrm{O}$ concentration in the atmosphere has increased at a rate of $0.26 \%$ per year, with more than $80 \%$ of the emissions associated with agricultural activities where organic (e.g., animal manures) or inorganic (e.g., synthetic fertilizers) sources of nitrogen $(\mathrm{N})$ are added to soil (IPCC, 2013). Manure application can result in more $\mathrm{N}_{2} \mathrm{O}$ emissions than inorganic $\mathrm{N}$ fertilizers (Watanabe et al., 2014; Zhou et al., 2017), and which we also observed in a drip-irrigated cotton field with low soil organic carbon in arid northwestern China (Kuang et al., 2018). However, it remains unclear whether the increased emissions with manure are linked with changes in the microbial community, especially those involved in the processes of nitrification and denitrification that lead to $\mathrm{N}_{2} \mathrm{O}$ production.

Nitrification is a biological oxidation process in which ammonia is converted to nitrate via nitrite $\left(\mathrm{NH}_{3} \rightarrow \mathrm{NH}_{2} \mathrm{OH} / \mathrm{HNO} \rightarrow \mathrm{NO}_{2}{ }^{-} \rightarrow \mathrm{NO}_{3}^{-}\right)$. The steps of nitrification are controlled by nitrifier functional genes, including (1) ammonia-oxidizing bacterial $(A O B)$ and (2) archaea $(A O A)$ genes, and (3) nitrite-oxidizing bacterial genes. The first step in the oxidation of ammonia to $\mathrm{NH}_{2} \mathrm{OH}$ limits the entire nitrification reaction (Kowalchuk \& Stephen, 2001). Applications of manure or inorganic $\mathrm{N}$ can exert a significant impact on nitrification. For example, Tao et al. (2017) reported that fertilizer $\mathrm{N}$ drives the abundance, community structure, and activity of nitrifying bacteria. Long-term application of manure and inorganic fertilizers reduced the copy number of $A O A$ but increased that of $A O B$ for agricultural soils in the cold climate of northeast China (Fan et al., 2011). For desert topsoil in Arizona, USA, long-term inorganic $\mathrm{N}$ addition did not affect the community structure of ammonia-oxidizing microorganisms but increased the amoA gene 
63

64

65

abundance of both $A O A$ and $A O B$ (Marusenko, Garcia-Pichel \& Hall, 2015). In contrast, a recent study of fertilized subtropical forest soils in southern China found that soil factors such as $\mathrm{NH}_{4}{ }^{+}$ concentration and $\mathrm{pH}$-controlled nitrification and denitrification activities, rather than the abundance and community structure of N-cycling prokaryotes (Tang et al., 2019).

$$
\text { Denitrification is a multi-step reduction process of } \mathrm{NO}_{3}{ }^{-} \text {to } \mathrm{N}_{2}\left(\mathrm{NO}_{3}^{-} \rightarrow \mathrm{NO}_{2}{ }^{-} \rightarrow \mathrm{NO} \rightarrow \mathrm{N}_{2} \mathrm{O} \rightarrow \mathrm{N}_{2}\right)
$$

mediated mainly by many bacteria under limited oxygen conditions. Specific reductases encoded by functional genes regulate each step of the reaction, including, nitrate reductase (e.g., narG, napA), nitrite reductase (e.g., nirS, nirK), nitric oxide reductase (e.g., cnorB, qnorB) and nitrous oxide reductase (nosZ; Simon \& Klotz, 2013). Changes in the abundance and community structure of denitrifiers can largely explain the increase in denitrification associated with fertilizer application (Yin et al., 2015). In a 160-year-long field experiment, Clark et al. (2012) reported long-term manure application increased denitrification compared to inorganic $\mathrm{N}$ fertilizer addition, which was mainly attributed to increased abundance of nirK- but not nirS-type denitrifiers. In contrast, several other studies reported that soil properties such as soil water content and $\mathrm{N}$ availability other than the abundance of denitrifier, deterimined the rate of denitrification (Attard et al., 2011; Shrewsbury et al., 2016).

Nitrogen additions can affect soil microbial community directly by supplying substrates for microorganisms or indirectly by changing soil properties. Application of animal manure can increase microbial biomass and diversity by providing carbon sources for microorganisms. In contrast, inorganic $\mathrm{N}$ application generally reduces soil microbial community diversity. For example, Zhang et al. (2017) recently reported that the application of inorganic fertilizers to acidic and near-neutral soils in a maize-vegetable rotation in southwest China significantly reduced bacterial diversity. Sun et al. (2015) also reported that the application of inorganic fertilizer to a 
86

87

wheat-soybean rotation for 30 years in central China reduced soil bacterial richness and diversity. Application of inorganic fertilizer affected the soil microbial community mainly by decreasing soil pH (Geisseler \& Scow, 2014).

As a dominant cash crop in northwestern China, cotton receives intensive inputs of inorganic fertilizers and more recently, water as drip-irrigation (Dai \& Dong, 2014). Cattle and sheep manure are also often used as nutrient sources due to their availabilities from olocal livestock production. In this region, manure application can greatly increase $\mathrm{N}_{2} \mathrm{O}$ emissions compared with granular urea, although emissions under drip irrigation were generally low (Kuang et al., 2018; Ma et al., 2018). Both nitrification and denitrification could play a role in production and emission of $\mathrm{N}_{2} \mathrm{O}$ under field conditions. It remains unclear how additions of organic manure or inorganic fertilizer affect the gene abundances and activity of nitrifier and denitrifier communities under drip irrigated conditions.

The objective of this study was to determine the influence of inorganic fertilizer and manure application to soil on the abundance and activities of $\mathrm{N}_{2} \mathrm{O}$-producing functional genes, as well as bacterial community structure in a drip-irrigated cotton field. We hypothesized that $\mathrm{N}_{2} \mathrm{O}$ emissions would increase with manure application and the abundance and activity of denitrifiers and not nitrifiers.

\section{MATERIALS \& METHODS}

\section{Site description and experimental design}

A plot based field experiment was conducted at the Cele Research Station $\left(37^{\circ} 01^{\prime} \mathrm{N}, 80^{\circ} 43^{\prime} \mathrm{E}\right)$ of the Chinese Academy of Sciences in the 2015 and 2016 summer growing seasons. The region has a typically arid continental climate with an extremely low long-term average annual precipitation 
109 of only $42 \mathrm{~mm}$, mainly distributed between May and July. The long-term average mean annual air

110 temperature is $12.7^{\circ} \mathrm{C}$. The soil is classified as Aridisols in the USDA soil taxonomy system or

111 Gypsisol in the FAO World Reference Base for Soil Resources. At the start of the study, the surface

112 soil $\left(0-20 \mathrm{~cm}\right.$ ) was a fine sand texture (sand 90\%, silt 4\%, clay 6\%) with bulk density $1.46 \mathrm{Mg} \mathrm{m}^{-3}$,

$113 \mathrm{pH}_{\mathrm{H} 2 \mathrm{O}} 8.0$, electrical conductivity $(\mathrm{EC}) 144.4 \mu \mathrm{S} \mathrm{cm}^{-1}$, total Kjeldahl $\mathrm{N} 0.31 \mathrm{~g} \mathrm{~kg}^{-1}$, extractable

$114 \mathrm{NO}_{3}{ }^{-}-\mathrm{N} 25.7 \mathrm{mg} \mathrm{kg}^{-1}, 0.5 \mathrm{M} \mathrm{NaHCO}_{3}$-extractable $\mathrm{P} 14.6 \mathrm{mg} \mathrm{kg}^{-1}, 1.0 \mathrm{M}^{2}$ ammonium acetate $\mathrm{K} 153$

$115 \mathrm{mg} \mathrm{kg}^{-1}$, and organic matter $6.9 \mathrm{~g} \mathrm{~kg}^{-1}$. Analysis of soil characteristics was based on Carter (1993).

116 Before this study, the experimental field was cropped to cotton for over five years and received

117 both manure and urea applications each year, in accordance with local farmer practice.

118 The experimental design was previously described in Kuang et al. (2018) and only treatments

119 under drip irrigation used in the current study. Briefly, the study was a randomized complete block

120 design of four treatments with four replicate plots for a total of 16 plots. Each plot was $10 \mathrm{~m}$ long

$121 \times 6 \mathrm{~m}$ wide and was separated from the other plots by a 1.1-m non-cropped buffer area. Treatments

122 included (1) an unfertilized control (Control), and application of $240 \mathrm{~kg}$ of available $\mathrm{N} \mathrm{ha}^{-1}$ in the

123 form of (2) granular urea (Urea, 46-0-0), (3) mixture of sheep and cattle manure compost (Manure),

124 and (4) 50\% urea with 50\% manure by weight (U+M). Local producers commonly use such $\mathrm{N}$

125

126

127

128

129

130

131 application rates for high-yielding cotton fields. For the Urea treatment, $20 \%$ of added $\mathrm{N}$ was banded in the plant row before planting, and the rest was applied with irrigation water as a schedule of $5 \%$ at 9 weeks, and $15 \%$ of added $\mathrm{N}$ each at $11,14,15,16$ and 17 weeks after planting. The manure was all applied before planting by broadcast-incorporation at $10 \mathrm{~cm}$ depth. The manure had a moisture content of $25 \%$ and a dry weight-based total N, P, K content of 15.6, 2.0, and 16.8 $\mathrm{g} \mathrm{kg}^{-1}$, respectively. Analysis of manure was done on subsamples digested with a mixture of perchloric, sulfuric and hydrofluoric acid. Total $\mathrm{P}$ and $\mathrm{K}$ in the acid digestion were measured using 
132 the Mo-Sb colorimetric method and atomic absorption spectrometry (ICE3500, Thermo Fisher, 133 USA), respectively. Total $\mathrm{N}$ was determined colorimetrically after Kjeldahl digestion. The manure

134 had an available $\mathrm{N}$ concentration of $29 \mathrm{mg} \mathrm{N} \mathrm{kg}^{-1}$, determined by the alkaline hydrolyze method.

135 In each year, cottonseed (c.v. Xinluzao 48, Huiyuan Tech, Shihezi, China) was planted at $75 \mathrm{~kg}$ $136 \mathrm{ha}^{-1}$ in early to middle April under plastic-mulch and drip-irrigated, which is typical of recent 137 cotton production in the region. Details on the system were described by Kuang et al. (2018). 138 Before seeding, all plots received a broadcast-incorporated application of $120 \mathrm{~kg} \mathrm{P}_{2} \mathrm{O}_{5} \mathrm{ha}^{-1}$ as 139 calcium phosphate and $60 \mathrm{~kg} \mathrm{~K}_{2} \mathrm{O}$ ha $^{-1}$ as $\mathrm{K}_{2} \mathrm{SO}_{4}$.

\section{Soil sampling}

142 Soil samples (0-20 cm depth) were collected with a hand auger (2.5 cm diameter) in September 1432016 with cotton at the boll opening stage. For each plot, four soil cores were collected next to the

drip tape and mixed thoroughly together for one composite sample per plot. The auger was cleaned using 95\% alcohol and wiped with sterile paper before collecting the next soil sample. Each sample was passed through a $2 \mathrm{~mm}$ mesh screen and partitioned into three subsamples. One subsample was air-dried at room temperature for chemical analysis. The second subsample for analysis of denitrifying enzyme activity (DEA) and nitrifying enzyme activity (NEA) was stored at $-20^{\circ} \mathrm{C}$ and analyzed within one week. The third subsample for microbial molecular analysis was stored at $80^{\circ} \mathrm{C}$.

\section{Soil chemical properties}

Soil $\mathrm{NH}_{4}^{+}$and $\mathrm{NO}_{3}^{-}$was extracted using $0.01 \mathrm{M} \mathrm{CaCl}_{2}$ and measured with a continuous flow analyzer (SEAL Analytical, Norderstedt, Germany). Soil pH was measured at 1:2.5 soil:water 
155 ratio. Soil total $\mathrm{C}$ was measured using by wet oxidation method with potassium dichromate. Total

$156 \mathrm{~N}$ was analyzed by Kjeldahl acid-digestion method with a Kjeltec 1035 analyzer (Tecator AB,

157 Sweden). Available Fe and $\mathrm{Cu}$ were extracted with DPTA (0.005 M diethylenetriamine pentaacetic

158 acid + 0.1 M triethanolamine + 0.01 $\mathrm{M} \mathrm{CaC1}_{2}$ set to $\left.\mathrm{pH} 7.3\right)$ and analyzed using ICP-OES (730ES,

159 VARIAN, USA). Soil dissolved organic carbon (DOC) was extracted using deionized water (1:5

160 soil:water ratio) and analyzed using a TOC analyzer (Aurora 1030W, OI Analytical, USA). Soil

$161 \mathrm{C}: \mathrm{N}$ ratio was calculated on mass basis of total $\mathrm{C}$ and total $\mathrm{N}$.

162

\section{Determination of denitrifying and nitrifying enzyme activity}

164

165

166

167

168

169

170

171

172

173

174

175

176

177

The frozen soil samples were pre-incubated to thaw at $25^{\circ} \mathrm{C}$ for two days before analysis of DEA and NEA. Soil DEA was expressed as the rate of $\mathrm{N}_{2} \mathrm{O}$ production $\left(\mu \mathrm{g} \mathrm{N} \mathrm{h}^{-1} \mathrm{~g}^{-1}\right.$ soil) and determined using the anaerobic slurry technique (Beauchamp \& Bergstrom, 1993). Briefly, $25 \mathrm{~g}$ thawed soil samples were placed into $125 \mathrm{ml}$ plasma flasks. $25 \mathrm{ml}$ solution including $10 \mathrm{mM} \mathrm{KNO}_{3}, 10 \mathrm{mM}$ glucose, $50 \mathrm{mM} \mathrm{K}_{2} \mathrm{HPO}_{4}$, and $0.1 \mathrm{~g} \mathrm{~L}^{-1}$ chloramphenicol to inhibit new protein production was added to each flask. The flasks were evacuated and flushed with a 90:10 $\mathrm{He}-\mathrm{C}_{2} \mathrm{H}_{2}$ gas mixture to create anaerobic conditions and suppress $\mathrm{N}_{2} \mathrm{O}$-reductase activity. Flasks were then shaken for 60 min and gas samples taken $0,15,30,45$, and 60 min after the onset of mixing using an orbital shake $(180 \mathrm{rpm})$. Concentrations of $\mathrm{N}_{2} \mathrm{O}$ in gas samples were immediately analyzed using gas chromatography equipped with an electron capture detector (Agilent 7890A, Agilent Technologies, USA).

Soil NEA was expressed as $\mu \mathrm{g} \mathrm{NO}_{3}^{-}-\mathrm{N} \mathrm{h}^{-1} \mathrm{~g}^{-1}$ dry soil and determined according to Hart et al. (1994). Briefly, a thawed soil sample (15 g dry soil equivalent) was placed into a $250 \mathrm{ml}$ plasma flask with $100 \mathrm{ml}$ solution of $1.5 \mathrm{mM}\left(\mathrm{NH}_{4}\right)_{2} \mathrm{SO}_{4}$ and $1 \mathrm{mM}$ phosphate buffer $(\mathrm{pH}=7.2)$. The flask 
178

179

180

181

182

183

184

was incubated at room temperature under constant agitation $(180 \mathrm{rpm})$. Samples of the slurry were taken at $2,4,8,12$, and $24 \mathrm{~h}$ during incubation. Concentrations of $\mathrm{NO}_{2}{ }^{-}$and $\mathrm{NO}_{3}{ }^{-}$in the samples was then determined using the continuous flow analyzer. NEA rate was calculated from the slope of the regression model of $\mathrm{NO}_{2}^{-}$plus $\mathrm{NO}_{3}{ }^{-}$concentrations and time.

\section{Soil DNA extraction and real-time PCR}

Soil DNA was extracted from $0.3 \mathrm{~g}$ of a soil sample using the Power Soil Total DNA Isolation Kit (MO-BIO Laboratories Inc., USA) according to the manufacturer's instructions. The quality and concentration of DNA were estimated using a Nanodrop 1000 Spectrophotometer (Thermo Fisher, USA) and gel electrophoresis (1.0\% agarose). The DNA extracts were diluted at a ratio of 1:10 with double-distilled water $\left(\mathrm{ddH}_{2} \mathrm{O}\right)$ to reduce the potential for PCR inhibition and then stored at $-20^{\circ} \mathrm{C}$ until use.

Quantitative PCR was used to quantify archaeal amoA and bacterial amoA, narG, nirK, nirS, and nosZ gene in triplicate. All reactions were carried out using a CFX96 ${ }^{\mathrm{TM}}$ (BIO-RAD, Laboratories Inc., USA). Each PCR reaction mixture contained $1 \mu 1$ of 10 -fold diluted soil DNA as a template, $10 \mu \mathrm{S} \mathrm{SYBR}{ }^{\circledR}$ Premix Ex Taq ${ }^{\mathrm{TM}} \mathrm{II}$ (TaKaRa, Japan), $0.8 \mu$ of primer $(10 \mu \mathrm{M})$, and 7.4 $\mu \mathrm{l} \mathrm{ddH}_{2} \mathrm{O}$ in a total volume of $20 \mu \mathrm{l}$. Primers and thermocycling conditions used in the qPCR reactions are given in Table 1. Plasmids containing respective sequences of the targeted genes were generated by cloning the targeted gene fragments from soil DNA into plasmid $\mathrm{pMD}^{\mathrm{TM}} 19-\mathrm{T}$ Vector (TaKaRa, Japan). Standard curves for each gene were created from 10-fold serial dilutions $\left(10^{8}-10^{1}\right)$ of the known quantities of linearized plasmid DNA harboring the target gene sequences. All qPCR reactions were conducted in triplicate. The qPCR efficiency and slope were 92\% and $3.5\left(\mathrm{R}^{2}=0.990\right)$ for archaeal $a m o A, 105 \%$ and $-3.2\left(\mathrm{R}^{2}=0.999\right)$ for bacterial $a m o A, 90 \%$ and -3.7 
$201\left(\mathrm{R}^{2}=0.999\right)$ for $n a r G, 85 \%$ and $-3.7\left(\mathrm{R}^{2}=0.997\right)$ for $\operatorname{nir} S, 96 \%$ and $-3.4\left(\mathrm{R}^{2}=0.998\right)$ for $n i r K$, and

$20280 \%$ and $-3.5\left(\mathrm{R}^{2}=0.990\right)$ for $n o s Z$, respectively. The generally low qPCR efficiency for $n i r S$ and 203 nos $Z$ genes agreed with previous studies reporting similar levels (74-90\%, Ding et al., 2014; 204 Harter et al., 2014).

205

206 High-throughput sequencing

207 The 16S rRNA gene of the V3-V4 hypervariable region was analyzed by MiSeq sequencing on 208 the Illumina Miseq $2 \times 300$ bp platform at Shanghai Sangon Biotech Co., Ltd. with the universal 209 primers 515F (GTGCCAGCMGCCGCGG) and 907R (CCGTCAATTCMTTTRAGTTT) that amplify both bacteria and archaea DNA (Li et al., 2014). Both forward and reverse primers were added with a barcode. The thermocycling program was set as: an initial denaturation at $94^{\circ} \mathrm{C}$ for 3 min, 5 cycles at $94^{\circ} \mathrm{C}$ for $30 \mathrm{~s}, 45^{\circ} \mathrm{C}$ for $20 \mathrm{~s}, 65^{\circ} \mathrm{C}$ for $30 \mathrm{~s}$ of extension, then 20 cycles of $94^{\circ} \mathrm{C}$ for $20 \mathrm{~s}, 55^{\circ} \mathrm{C}$ for $20 \mathrm{~s}, 72^{\circ} \mathrm{C}$ for $30 \mathrm{~s}$, with a final extension at $72^{\circ} \mathrm{C}$ for $5 \mathrm{~min}$. The reactions were set as: $15 \mu \mathrm{l} 2 \times$ Taq Master Mix (Thermo Scientific, USA), $2 \mu \mathrm{l}$ of DNA template (about $20 \mathrm{ng}$ ), $1 \mu \mathrm{l}$ of each appropriate primer $(10 \mu \mathrm{M}), 11 \mu \mathrm{l}$ of $\mathrm{ddH}_{2} \mathrm{O}$. The PCR products were purified and quantified using the Agencourt AMPure XP (Beckman Coulter, USA) reagent and Qubit $^{\mathrm{TM}}$ ssDNA Assay Kit (Life Technologies, USA), respectively. Finally, the purified PCR products of each sample were equally combined based on their concentrations and produced a DNA pool which included 16S rRNA gene amplified fragments for sequencing.

220 Sequencing reads were allocated to each sample based on their unique barcodes. Raw sequences were firstly processed using cutadapt software (v 1.2.1) to trim the barcodes of their primers. Two 222 short Illumina reads were then merged with PEAR (v 0.9.6) software (Zhang et al., 2014), and 223 finally, PRINSEQ software (v 0.20.4, Schmieder \& Edwards, 2011) was used for quality control 
224 of the merged reads. Only sequences $>200 \mathrm{bp}$ in length with an average quality score $>40$ were

225 used for further analyses. Chimeras were filtered by comparing the sequences with those in the

226 reference database using the UCHIME algorithm (v 4.2.40, Edgar et al., 2011). After the above

227 screening, the remaining high-quality sequences were clustered into Operational Taxonomic Units

228 (OTUs) at a $\geq 97 \%$ similarity identity threshold. The singletons and low abundance OTUs were

229 removed before further analyses. The Ribosomal Database Project (RDP) classifier (Wang et al.,

230 2007) was used to identify taxonomic information at the bootstrap cutoff of $80 \%$. Based on the

231 OTUs output, $\alpha$-diversity, and $\beta$-diversity, and canonical correspondence analysis were performed.

232 Species richness and diversity indices, including coverage, Chao1, ACE, Simpson, and Shannon

233 were calculated using mothur (v 1.30.1, Schloss et al., 2009) to estimate the $\alpha$-diversity of each 234 sample.

235

236 Statistical analysis

237 Treatment effects on soil properties, NEA, DEA, $\alpha$-diversity indices, and bacterial gene 238 abundances were conducted using a one-way ANOVA. Pearson correlation analysis was 239 conducted to assess the relationships between the functional gene abundances, NEA, DEA, and 240 selected soil properties. ANOVA and Pearson correlation analysis was performed with SAS 9.3 241 (SAS Institute, USA) and differences were considered significant at $P<0.05$. Principal coordinates 242 analysis (PCoA) was performed to determine the community $\beta$-diversity of bacteria using the 243 Vegan package Version 1.17-7 (Oksanen, 2011) implemented with the R language, which was 244 based on a bacterial weighted UniFrac metric matrix. Canonical correspondence analysis (CCA) 245 was performed with the Vegan package implemented with the $\mathrm{R}$ language to determine the 246 relationships between soil physicochemical properties and bacterial communities. Untransformed 
247 data were used for the PCoA and CCA analyses. The relative abundances of bacterial community

248 at the phylum level between treatments were compared using the Welch's t-test with STAMP

249 (Statistical Analysis of Metagenomic Profiles). Corrected p-values of the Welch's t-test were 250 calculated using the FDR (False Discovery Rate) for multiple testing correction.

251

252 RESULTS

253 Soil chemical characteristics

254 Manure and $\mathrm{U}+\mathrm{M}$ treatments increased soil total $\mathrm{N}$ content by half compared to the unfertilized 255 control (Table 2). Soil $\mathrm{NO}_{3}{ }^{-}$concentrations with Manure and $\mathrm{U}+\mathrm{M}$ treatments were 120 and 103 $256 \mathrm{mg} \mathrm{kg}^{-1}$, respectively, being 2.4-4.8 times greater than the Urea and Control treatments. In contrast, 257 soil $\mathrm{NH}_{4}{ }^{+}$concentrations were not affected by the treatments. Soil total $\mathrm{C}$ and DOC were also 258 greater in Manure and $\mathrm{U}+\mathrm{M}$ compared to the Control and Urea treatments. As a result, treatments 259 with manure addition (Manure and $\mathrm{U}+\mathrm{M}$ ) had 37-100\% higher soil $\mathrm{C}: \mathrm{N}$ ratios, compared to Urea 260 and Control.

\section{Denitrifying enzyme activity and nitrifying enzyme activity}

Manure and $\mathrm{U}+\mathrm{M}$ treatment significantly $(P<0.001)$ increased DEA levels compared to the Urea and Control treatments (Fig. 1A). In contrast, NEA levels did not respond significantly to any amendment treatment in spite of an increasing trend from control to urea and manure additions (Fig. 1B).

267

Bacterial community, and nitrifier and denitrifier gene abundances

269 The sequence coverage index ranged between 0.93 and 0.94 , suggesting that the sequencing depth 
270 was sufficient to obtain the majority of genetic diversity of samples (Table 3 ). The average number

271 of valid sequences were similar for treatments, being $27,131,28,812,26,413$, and 30,405 , for

272 Control, Urea, Manure, and U+M, respectively, with a mean read length of $376 \mathrm{bp}$. The number

273 of OTUs was not affected by $\mathrm{N}$ addition and ranged between 4,072 and 4,295. The indexes of

274 richness and diversity, Chao1, ACE, Simpson, and Shannon were also not affected by the 275 treatments.

276 The addition treatments resulted in an apparent clustering in $\beta$-diversity of the soil bacterial 277 community (Fig. 2). Two groups with (Manure and U+M) and without (Control and Urea) manure application occurred along axis PCoA1, with a significant dissimilarity $(P<0.001)$. The PCoA explained $73 \%$ of the total variation in the composition of the bacterial community, with PCoA1 and PCoA2 explaining 61\% and 12\%, respectively. At the bacterial phylum level, the abundance

of Planctomycetes, Bacteroidetes, and Ignavibacteriae increased with manure additions, whereas that of Latescibacteria, Acidobacteria, Armatimonadetes, Actinobacteria, and candidate division WPS-2 decreased (Table 4). There was no treatment effect on the abundance of Proteobacteria.

At archaeal phylum level, the abundance of Thaumarchaeota and Euryarchaeota decreased with manure application.

Manure and $\mathrm{U}+\mathrm{M}$ treatments doubled the gene copy number of $A O A$ (Fig. 3A). Similarly, manure application also significantly $(P<0.001)$ increased the copy number of the $A O B$ gene in manure than non-manure amended treatments. The copy number of $A O A$ was generally one order of magnitude greater than that of $A O B$. Further, $A O B$ copy number responded more to treatment additions than that of $A O A$. As a result, manure addition reduced the ratio of $A O A / A O B$, being 88.7, 27.6, 15.8, and 17.0 for Control, Urea, Manure, and U+M, respectively.

Manure addition significantly $(P<0.001)$ increased the copy number of narG, nirK or nosZ 
293

294

295

296

297

298

299

300

301

302

303

304

305

306

307

308

309

310

311

312

314 315

313 DISCUSSION

genes, but did not affect that of nirS (Fig. 3B-E). Copy number of $n a r G$ was 27.5-39.0 times greater

with manure (U+M and Manure) than non-manure (Control and Urea) addition treatments. Copy

number of nirK was 3.4-3.7 times greater with manure than non-manure addition treatments.

Similarly, the copy number of nos $Z$ gene were 9.6-25.2 times greater in manure than non-manure addition treatments.

\section{Relationships between DEA, NEA, soil properties and microbial abundance}

Copy number of nitrifier $(A O B$ and $A O A)$, nitrate reducer (narG), nirK, and nosZ-type denitrifier genes, but not nirS-type denitrifier gene, were positively correlated with $\mathrm{NO}_{3}{ }^{-}, \mathrm{DOC}$, total $\mathrm{N}$, total $\mathrm{C}$, and $\mathrm{C}: \mathrm{N}$ ratio (Table 5). In contrast, soil $\mathrm{NH}_{4}{ }^{+}$and $\mathrm{pH}$ were not significantly correlated with the copy number of any of the functional genes. There were also significant positive correlations between DEA and abundance of $A O B, A O A$, narG, nirK, and nosZ genes. NEA, however, was not correlated with the abundance of any functional gene, except for a positive correlation with nirK.

The bacterial $\beta$-diversity was highly associated with changes in soil environmental variables (Fig. 4). The first and second axes explained the variance in bacterial community structure to $38.6 \%$ and $13.9 \%$, respectively. The bacterial community of manure addition treatments (Manure and $\mathrm{U}+\mathrm{M}$ ) was mainly associated with soil concentrations of $\mathrm{NO}_{3}{ }^{-}, \mathrm{DOC}$, total $\mathrm{C}$, total $\mathrm{N}$, and $\mathrm{C}: \mathrm{N}$ ratio. In contrast, the bacterial community of treatments without manure addition (Control and Urea) was mainly associated with soil $\mathrm{pH}$.

Manure application exerted a significant effect on microbial abundance and beta diversity and greatly increased the DEA compared with conventional urea. We further linked the increase of 
316 DEA by manure application with changes in denitrifier abundance. The increased denitrification

317 activity with manure application was in accordance with the increasing abundance of nitrate

318 reducer (narG), and nirK- or nosZ-type denitrifiers. It should be noted, however, soil samplings

319 were conducted for only one time over the growing season for determination of soil microbial

320 activities in the current study, which hindered the investigations of temporal changes in soil

321 microbes and could also cause uncertainties in correlating with $\mathrm{N}_{2} \mathrm{O}$ emissions. Still, sampling was

322 done in a representative field for the local cotton production where we compared farmer's

323 management practices of applying manure relative to inorganic fertilizers. The sampling depth (0-

$32420 \mathrm{~cm}$ ) for microbial analysis was also in accordance with previous findings that soil $\mathrm{N}_{2} \mathrm{O}$

325 emissions following $\mathrm{N}$ addition were mostly attributed to the topsoils (Wagner-Riddle et al., 2008;

326 Kuang et al., 2019).

327

\section{Impact of $\mathbf{N}$ addition strategy on denitrification and nitrification}

329 The increased activity of soil denitrifying enzymes with manure in the current study is inconsistent with our findings at the same field where we reported more $\mathrm{N}_{2} \mathrm{O}$ emissions from manure compared with urea application under drip irrigation conditions (Kuang et al., 2018). The increased $\mathrm{NO}_{3}{ }^{-}$and carbon supply with manure application could likely have provided the primary substrate for denitrification and increased the $\mathrm{N}_{2} \mathrm{O} /\left(\mathrm{N}_{2} \mathrm{O}+\mathrm{N}_{2}\right)$ ratio (Francis et al., 2013). Chantigny et al. (2010) also suggested that manure can elevate soil respiration and deplete $\mathrm{O}_{2}$ concentration to create temporary anaerobic conditions, thereby further increasing the proportion of $\mathrm{N}_{2} \mathrm{O}$ production through denitrification. These studies highlight the importance of $\mathrm{N}$ addition source on soil $\mathrm{N}$ transformation processes and suggest that manure induced $\mathrm{N}_{2} \mathrm{O}$ emissions are likely attributed to denitrification. 
339

340

341

342

343

344

345

346

347

348

349

350

351

352

353

354

355

356

357

358

359

360

361

In contrast to DEA, NEA was not affected by manure application in the current study. Similarly, Shen et al. (2008) also reported that organic manure did not affect potential nitrification rates of an alkaline sandy loam soil in northern China. Several studies suggested that soil $\mathrm{pH}$ is the dominant factor for nitrification as it determines the availability of $\mathrm{NH}_{4}^{+}$, which is the primary substrate for ammonia oxidation, the initial and rate-limiting step of nitrification (Fan et al., 2011; Nicol et al., 2008). In our study, both $\mathrm{pH}$ and the availability of $\mathrm{NH}_{4}^{+}$were not affected by $\mathrm{N}$ addition strategy, confirming the insensitivity of NEA to N sources.

In contrast with manure, urea did not significantly affect DEA and NEA compared to Control. Our results agree with those of Yin et al. (2015), who reported that manure but not inorganic fertilizer increased denitrification potential. In contrast, application of inorganic $\mathrm{N}$ fertilizers increased the activity of nitrification (Fang et al., 2018; Shi et al., 2016) and potential denitrification (Duan et al., 2017; Wang et al., 2018). The absence of the inorganic fertilizer effect in the current study was associated with the minor to no effect by urea application on soil properties such as $\mathrm{pH}$, DOC and inorganic $\mathrm{N}\left(\mathrm{NO}_{3}{ }^{-}\right.$and $\left.\mathrm{NH}_{4}{ }^{+}\right)$compared with Control. It is likely the buildup of $\mathrm{C}$ and $\mathrm{N}$ substrates by urea application were not sufficient enough to affect the activities of functional genes.

\section{Impact of $\mathrm{N}$ addition strategy on the abundance of functional genes and bacterial community} structure

In the current study, the positive relationships of the abundances of nar $G$, nirK and nos $Z$ with DEA and further with soil DOC, total $\mathrm{C}$, and total $\mathrm{N}$ suggest that manure significantly increased gene abundance by providing $\mathrm{C}$ and $\mathrm{N}$ substrate. This result is in line with the previous findings that the denitrifiers abundance could be used as a predictor of DEA (Morales, Cosart \& Holben, 2010). 
362 Our findings also agree with previous studies which reported that organic manure increased the 363 abundance of nosZ-type denitrifier compared to inorganic fertilizers (Hallin et al., 2009; Tao et 364 al., 2018). Also being consistent with previous studies (Zhou et al., 2011), the abundance of nirK 365 but not nirS was increased by manure application in this study, suggesting that nirK was more

366

367

368

369

susceptive to fertilizer regimes than nirS-type denitrifier. Hallin et al. (2009) also reported that denitrification rates were not correlated with the abundance of nirS genes in soils treated with different fertilizer regimes for 50 years. A possible reason for the lack of correlation could be that the denitrifier harbouring the nirS gene might play a minor functional role for DEA (Attard et al., 2011). In the current study, the nitrate reducer (narG), and nirK-and nosZ-type denitrifiers, which encodes the main catalytic enzymes responsible for nitrate reduction, nitrite reduction, and $\mathrm{N}_{2} \mathrm{O}$ reduction respectively, were more sensitive to manure application. The increase of the denitrifiers abundance with manure application thus increased the pool of denitrifying enzymes. Even though the limited soil sampling for microbial analysis hindered the possibility of directly linking results from the current study to the in-situ measurements of $\mathrm{N}_{2} \mathrm{O}$ flux, the positive relationship between DEA and the abundance of denitrifiers suggest the manure-induced $\mathrm{N}_{2} \mathrm{O}$ emissions in Kuang et al. (2018) was more likely determined by denitrification.

It is interesting to note that manure application increased $A O A$ and $A O B$ whereas did not affect NEA in this study, suggesting the abundance of ammonia-oxidizers are not necessarily associated with nitrification potential. Nicol et al. (2008) reported that the activity of ammonia-oxidizers was more associated with the relationships among transcription, translation, and enzyme function rather than the abundance of functional genes. It is also likely that the complicated subsequent hierarchical regulation of enzyme expression resulted in an uncouple effect between NEA and amoA gene abundance (Röling, 2010). Consistent with previous studies (Fan et al., 2011; Tian et 
385

386

387

388

389

390

391

392

393

394

395

396

397

398

399

400

401

402

403

404

405

406

407

al., 2014), $\mathrm{N}$ addition reduced the $A O A / A O B$ ratio in this study, suggesting that $A O A$ and $A O B$ may occupy different soil niches due to the differences in physiological and metabolic pathways. Previously, $A O A$ prefers low $\mathrm{NH}_{3}$ substrate conditions for growth, whereas $A O B$ prefers higher $\mathrm{NH}_{3}$ levels (Di et al., 2010), thus potentially resulting in a lower $A O A / A O B$ ratio following $\mathrm{N}$ addition.

Similar to previous studies (Ji et al., 2018; Kumar et al., 2018; Wang et al., 2019), manure application significantly changed $\beta$-diversity of soil bacterial community in the current study. The PCoA analysis revealed a dominant contribution of PCoA1 (61\%) to total variation and a clear separation of manure vs. non-manure groups along the axis PCoA1. This suggests that the addition of manure was a key factor determining the variation in the bacterial community among treatment. Clearly, the increased $\mathrm{N}$ and $\mathrm{C}$ substrates with manure application have increased the growth of some specific microbial groups and suppress others and thus changed the composition of the soil microbial community. The absence of urea effect on the $\beta$-diversity of the bacterial community was attributed to the low organic matter content $\left(6.6 \mathrm{~g} \mathrm{~kg}^{-1}\right)$, suggesting that the substrate deficiency of $\mathrm{C}$ limited microbial activities under the conditions in this study. In this study, manure or urea applications did not influence $\alpha$-diversity of soil bacterial community, likely due to an absence effect on soil pH. Fierer \& Jackson (2006) reported that soil pH is the primary driver determining the $\alpha$-diversity and richness of the soil bacterial community.

In the current study, the changes of soil bacterial community structure in response to manure application were attributed to the increasing relative abundance of Planctomycetes, Bacteroidetes, lgnavibacteriae and decreasing abundance of Actinobacteria, Acidobacteria, Latescibacteria, Armatimonadetes, and candidate division WPS-2. These results highlight the change of eutrophic and oligotrophic bacteria. For example, Fierer et al. (2007) found that Bacteroidetes were typically 
408 copiotrophic bacteria and could thrive in soil with high available organic carbon. Planctomycetes

409 are involved in the turnover of soil organic carbon, and nutrient availability, and the reproduction

410 of this microbial group may increase intensively in response to the application of manure (Lupatini

411 et al., 2016). The phyla which were negatively influenced by manure application were considered

412 as slow-growing oligotrophs accustomed to nutrient-limited environments. For example, several

413 studies had shown that Acidobacteria strains grew slowly with their growth being limited to

414 substrate additions (Goldfarb et al., 2011).

415

416 CONCLUSIONS

417 Manure application significantly increased the abundances of nitrate reducer (narG), and nirK418 and nosZ-type denitrifier gene abundances and denitrifying enzyme activity. Additionally, soil 419 DOC, total $\mathrm{C}$, and total $\mathrm{N}$ contents increased with the abundances of narG, nirK, and nos $Z$ genes, 420 suggesting manure addition to soil stimulated production of these functional genes by providing 421 energy and $\mathrm{N}$ substrate. In contrast, urea application did not affect the abundances of nitrifier and 422 denitrifier functional genes. High throughput sequencing clearly showed that two years of manure 423 application significantly altered the bacterial community composition of soil. Consequently, our 424 study demonstrated a strong link between abundances of nitrate reducer (nar $G)$, nirK- and nosZ425 type denitrifier gene copies and enhanced DEA with manure application under drip-irrigation of 426 cotton. Together the results indicate denitrification was likely the key process leading to a manure427 induced increase in $\mathrm{N}_{2} \mathrm{O}$ emissions. 
429 Attard E, Recous S, Chabbi A, De Berranger C, Guillaumaud N, Labreuche J, Philippot L, Schmid B, Le 430 Roux X. 2011. Soil environmental conditions rather than denitrifier abundance and diversity drive potential 431 denitrification after changes in land uses. Global Change Biology 17:1975-1989 DOI 10.1111/j.1365432 2486.2010.02340.x.

433 Beauchamp EG, Bergstrom DW. 1993. Denitrification. In: Carter MR. (Ed.), Soil Sampling and Methods of 434 Analysis. Lewis Publishers, Boca Raton, FL, pp. 351-357.

435 Bru D, Sarr A, Philippot L. 2007. Relative abundances of proteobacterial membrane-bound and periplasmic 436 nitrate reductases in selected environments. Applied and Environmental Microbiology 73:5971-5974 DOI 437 10.1128/AEM.00643-07.

438 Carter MR. 1993. Soil Sampling and Methods of Analysis. Lewis Publishers, Boca Raton, FL.

439 Chantigny MH, Rochette P, Angers DA, Bittman S, Buckley K, Massé D, Bélanger G, Eriksenhamel N, 440 Gasser MO. 2010. Soil nitrous oxide emissions following band-incorporation of fertilizer nitrogen and swine 441 manure. Journal of Environmental Quality 39:1545-1553 DOI 10.2134/jeq2009.0482.

442 Clark IM, Buchkina N, Jhurreea D, Goulding KW, Hirsch PR. 2012. Impacts of nitrogen application rates on 443 the activity and diversity of denitrifying bacteria in the Broadbalk Wheat Experiment. Philosophical 444 Transactions of the Royal Society B-Biological Sciences 367:1235-1244 DOI 10.1098/rstb.2011.0314.

445 Dai J, Dong H. 2014. Intensive cotton farming technologies in China: Achievements, challenges and 446 countermeasures. Field Crops Research 155:99-110 DOI 10.1016/j.fcr.2013.09.017.

447 Di HJ, Cameron KC, Shen JP, Winefield CS, O'Callaghan M, Bowatte S, He JZ. 2010. Ammonia-oxidizing 448 bacteria and archaea grow under contrasting soil nitrogen conditions. FEMS Microbiology Ecology 72:386449394 DOI 10.1111/j.1574-6941.2010.00861.x.

450 Ding K, Zhong L, Xin, X. Xu Z, Kang X, Liu W, Rui Y, Jiang L, Tang L, Wang Y. 2015. Effect of grazing on 451 the abundance of functional genes associated with $\mathrm{N}$ cycling in three types of grassland in Inner Mongolia. 452 Journal of Soils and Sediments 15:683-693 DOI 10.1007/s11368-014-1016-z.

453 Duan R, Long X, Tang Y, Wen J, Su S, Bai L, Liu R, Zeng X. 2017. Effects of different fertilizer application 454 methods on the community of nitrifiers and denitrifiers in a paddy soil. Journal of Soils and Sediments 18:2445538 DOI $10.1007 /$ s11368-017-1738-9.

456 Edgar RC, Haas BJ, Clemente JC, Quince C, Knight R. 2011. UCHIME improves sensitivity and speed of 457 chimera detection. Bioinformatics 27:2194-2200 DOI 10.1093/bioinformatics/btr381.

458 Fan F, Yang Q, Li Z, Wei D, Cui XA, Liang Y. 2011. Impacts of organic and inorganic fertilizers on nitrification 459 in a cold climate soil are linked to the bacterial ammonia oxidizer community. Microbial Ecology 62:982-990 460 DOI 10.1007/s00248-011-9897-5.

461 Fang Y, Wang F, Jia X, Chen J. 2018. Distinct responses of ammonia-oxidizing bacteria and archaea to green 462 manure combined with reduced chemical fertilizer in a paddy soil. Journal of Soils and Sediments 19:16134631623 DOI 10.1007/s11368-018-2154-5.

464 Fierer N, Jackson RB. 2006. The diversity and biogeography of soil bacterial communities. Proceedings of the 465 National Academy of Sciences 103(3):626-631 DOI 10.1073/pnas.0507535103.

466 Fierer N, Bradford MA, Jackson RB. 2007. Toward an ecological classification of soil bacteria. Ecology 
468 Francis CA, O'Mullan GD, Cornwell JC, Ward BB. 2013. Transitions in nirS-type denitrifier diversity, 469 community composition, and biogeochemical activity along the Chesapeake Bay estuary. Frontiers in $470 \quad$ Microbiology 4:237-237 DOI 10.3389/fmicb.2013.00237.

471 Francis CA, Roberts KJ, Beman JM, Santoro AE, Oakley BB. 2005. Ubiquity and diversity of ammonia472 oxidizing archaea in water columns and sediments of the ocean. Proceedings of the National Academy of 473 Sciences 102:14683-14688 DOI 10.1073/pnas.0506625102.

474 Geisseler D, Scow KM. 2014. Long-term effects of mineral fertilizers on soil microorganisms - A review. Soil 475 Biology and Biochemistry 75:54-63 DOI 10.1016/j.soilbio.2014.03.023.

476 Goldfarb KC, Karaoz U, Hanson CA, Santee CA, Bradford MA, Treseder KK, Wallenstein MD, Brodie EL. 477 2011. Differential growth responses of soil bacterial taxa to carbon substrates of varying chemical 478 recalcitrance. Frontiers in Microbiology 2:94 DOI 10.3389/fmicb.2011.00094.

479 Hallin S, Jones CM, Schloter M, Philippot L. 2009. Relationship between N-cycling communities and ecosystem 480 functioning in a 50-year-old fertilization experiment. ISME Journal 3:597 DOI10.1038/ismej.2008.128.

481 Hart SC, Stark JM, Davidson EA, Firestone MK. 1994. Nitrogen mineralization, immobilization, and 482 nitrification. In: Weaver RW. (Ed.), Methods of Soil Analysis: II. Microbiological and Biochemical 483 Properties. SSSA, Madison, WI, pp. 985-1018.

484 Harter J, Krause HM, Schuettler S. Ruser R, Fromme M, Scholten T, Kappler A, Behrens S. 2014. Linking $485 \quad \mathrm{~N}_{2} \mathrm{O}$ emissions from biochar-amended soil to the structure and function of the N-cycling microbial 486 community. ISME Journal 8:660-674 DOI 10.1038/ismej.2013.160.

487 IPCC. 2013. Climate Change 2013: The Physical Science Basis. Cambridge University Press, New York, USA.

488 Ji L, Wu Z, You Z, Yi X, Ni K, Guo S, Ruan J. 2018. Effects of organic substitution for synthetic N fertilizer on 489 soil bacterial diversity and community composition: A 10-year field trial in a tea plantation. Agriculture, 490 Ecosystems \& Environment 268:124-132 DOI 10.1016/j.agee.2018.09.008.

491 Kowalchuk GA, Stephen JR. 2001. Ammonia-oxidizing bacteria: a model for molecular microbial ecology. 492 Annual Review of Microbiology 55:485 DOI 10.1146/annurev.micro.55.1.485.

493 Kuang W, Gao X, Gui D, Tenuta M, Flaten DN, Yin M, Zeng F. 2018. Effects of fertilizer and irrigation 494 management on nitrous oxide emission from cotton fields in an extremely arid region of northwestern China. $495 \quad$ Field Crops Research 229:17-26 DOI 10.1016/j.fcr.2018.09.010.

496 Kuang W, Gao X, Tenuta M, Gui D, Zeng F. 2019. Relationship between soil profile accumulation and surface 497 emission of $\mathrm{N}_{2} \mathrm{O}$ : effects of soil moisture and fertilizer nitrogen. Biology and Fertility of Soils 55:97-107 DOI $498 \quad 10.1007 / \mathrm{s} 00374-018-01337-4$.

499 Kumar U, Nayak AK, Shahid M, Gupta VV, Panneerselvam P, Mohanty S, Kaviraj M, Kumar A, Chatterjee 500 D, Lal B. 2018. Continuous application of inorganic and organic fertilizers over 47 years in paddy soil alters 501 the bacterial community structure and its influence on rice production. Agriculture, Ecosystems \& 502 Environment 262:65-75 DOI 10.1016/j.agee.2018.04.016.

503 Li C, Yan K, Tang L, Jia Z, Li Y. 2014. Change in deep soil microbial communities due to long-term fertilization. $504 \quad$ Soil Biology and Biochemistry 75:264-272 DOI 10.1016/j.soilbio.2014.04.023.

505 Lupatini M, Korthals GW, de Hollander M, Janssens TK, Kuramae EE. 2016. Soil microbiome is more 506 heterogeneous in organic than in conventional farming system. Frontiers in Microbiology 7:2064 DOI $507 \quad 10.3389 /$ fmicb.2016.02064. 
508 Ma Z, Gao X, Tenuta M, Kuang W, Gui D, Zeng F. 2018. Urea fertigation sources affect nitrous oxide emission 509 from a drip-fertigated cotton field in northwestern China. Agriculture Ecosystems \& Environment 265:22-30 510 DOI 10.1016/j.agee.2018.05.021.

511 Marusenko Y, Garcia-Pichel F, Hall SJ. 2015. Ammonia-oxidizing archaea respond positively to inorganic 512 nitrogen addition in desert soils. FEMS Microbiology Ecology 91:1-11 DOI 10.1093/femsec/fiu023.

513 Morales SE, Cosart T, Holben WE. 2010. Bacterial gene abundances as indicators of greenhouse gas emission in $514 \quad$ soils. ISME Journal 4:799-808 DOI 10.1038/ismej.2010.8.

515 Nicol GW, Leininger S, Schleper C, Prosser JI. 2008. The influence of soil pH on the diversity, abundance and 516 transcriptional activity of ammonia oxidizing archaea and bacteria. Environmental Microbiology 10:2966517 2978 DOI 10.1111/j.1462-2920.2008.01701.x.

518 Oksanen J. 2011. Multivariate analysis of ecological communities in R: vegan tutorial. R package version 1.17-7. $519 \quad$ URL:http://cc.oulu.fi/ jarioksa/opetus/metod i/vegantutor.pdf.

520 Ravishankara AR, Daniel JS, Portmann RW. 2009. Nitrous oxide $\left(\mathrm{N}_{2} \mathrm{O}\right)$ : the dominant ozone-depleting 521 substance emitted in the $21^{\text {st }}$ century. Science 326:123-125 DOI 10.1126/science.1176985

522 Röling WF. 2010. Do microbial numbers count? Quantifying the regulation of biogeochemical fluxes by 523 population size and cellular activity. FEMS Microbiology Ecology 62:202-210 DOI 10.1111/j.1574$524 \quad 6941.2007 .00350 . x$.

525 Rotthauwe JH, Witzel KP, Liesack W. 1997. The ammonia monooxygenase structural gene amo $A$ as a functional 526 marker: molecular fine-scale analysis of natural ammonia-oxidizing populations. Applied and Environmental 527 Microbiology 63:4704-4712 DOI 10.1126/science.284.5411.63.

528 Scala DJ, Kerkhof LJ. 1998. Nitrous oxide reductase (nos $Z$ ) gene-specific PCR primers for detection of 529 denitrifiers and three nos $Z$ genes from marine sediments. FEMS Microbiology Letters 162:61-68 DOI $530 \quad 10.1111 / \mathrm{j} .1574-6968.1998 . t b 12979 . x$.

531 Schloss P, Westcott S, Ryabin T, Hall J, Hartmann M, Hollister E, Lesniewski R, Oakley B, Parks D, 532 Robinson C, Sahl J, Stres B, Thallinger G, Van Horn D, Weber C. 2009. Introducing mothur: open-source, 533 platform-independent, community-supported software for describing and comparing microbial communities. 534 Applied and Environmental Microbiology 75:7537-7541 DOI 10.1128/AEM.01541-09.

535 Schmieder R, Edwards R. 2011. Quality control and preprocessing of metagenomic datasets. Bioinformatics 536 27:863-864 DOI 10.1093/bioinformatics/btr026.

537 Shen JP, Zhang LM, Zhu YG, Zhang JB, He JZ. 2008. Abundance and composition of ammonia-oxidizing 538 bacteria and ammonia-oxidizing archaea communities of an alkaline sandy loam. Environmental 539 Microbiology 10:1601-1611 DOI 10.1111/j.1462-2920.2008.01578.x.

540 Shi X, Hu HW, Kelly K, Chen D, He JZ, Suter H. 2016. Response of ammonia oxidizers and denitrifiers to 541 repeated applications of a nitrification inhibitor and a urease inhibitor in two pasture soils. Journal of Soils 542 and Sediments 17:974-984 DOI 10.1007/s11368-016-1588-x.

543 Shrewsbury LH, Smith JL, Huggins DR, Carpenter-Boggs L, Reardon CL. 2016. Denitrifier abundance has a 544 greater influence on denitrification rates at larger landscape scales but is a lesser driver than environmental 545 variables. Soil Biology and Biochemistry 103:221-231 DOI 10.1016/j.soilbio.2016.08.016.

546 Simon J, Klotz MG. 2013. Diversity and evolution of bioenergetic systems involved in microbial nitrogen 547 compound transformations. Biochimica et Biophysica Acta (BBA) - Bioenergetics 1827:114-135 DOI $548 \quad 10.1016 /$ j.bbabio.2012.07.005. 
549 Sun R, Guo X, Wang D, Chu H. 2015. Effects of long-term application of chemical and organic fertilizers on the 550 abundance of microbial communities involved in the nitrogen cycle. Applied Soil Ecology 95:171-178 DOI $551 \quad$ 10.1016/j.apsoil.2015.06.010.

552 Tang Y, Yu G, Zhang X, Wang Q, Tian D, Tian J, Niu S, Ge J. 2019. Environmental variables better explain 553 changes in potential nitrification and denitrification activities than microbial properties in fertilized forest 554 soils. Science of the Total Environment 647:653-662 DOI 10.1016/j.scitotenv.2018.07.437.

555 Tao R, Wakelin SA, Liang Y, Chu G. 2017. Response of ammonia-oxidizing archaea and bacteria in calcareous 556 soil to mineral and organic fertilizer application and their relative contribution to nitrification. Soil Biology 557 and Biochemistry 114:20-30 DOI 10.1016/j.soilbio.2017.06.027.

558 Tao R, Wakelin SA, Liang Y, Hu B, Chu G. 2018. Nitrous oxide emission and denitrifier communities in drip559 irrigated calcareous soil as affected by chemical and organic fertilizers. Science of the Total Environment 560 612:739-749 DOI 10.1016/j.scitotenv.2017.08.258.

561 Throback IN, Enwall K, Jarvis A, Hallin S. 2004. Reassessing PCR primers targeting nirS, nirK and nos $Z$ genes 562 for community surveys of denitrifying bacteria with DGGE. FEMS Microbiology Ecology 49:401-417 DOI $563 \quad 10.1016 /$ j.femsec.2004.04.011.

564 Tian XF, Hu HW, Ding Q, Song MH, Xu XL, Zheng Y, Guo LD. 2014. Influence of nitrogen fertilization on 565 soil ammonia oxidizer and denitrifier abundance, microbial biomass, and enzyme activities in an alpine 566 meadow. Biology and Fertility of Soils 50:703-713 DOI 10.1007/s00374-013-0889-0.

567 Wagner-Riddle C, Hu QC, Van Bochove E, Jayasundara S. 2008. Linking nitrous oxide flux during spring thaw 568 to nitrate denitrification in the Soil Profile. Soil Science Society of America Journal 72:908-916 DOI $569 \quad 10.2136 /$ sssaj2007.0353.

570 Wang Q, Garrity GM, Tiedje JM, Cole JR. 2007. Naive Bayesian classifier for rapid assignment of rRNA 571 sequences into the new bacterial taxonomy. Applied and Environmental Microbiology 73:5261-5267 DOI $572 \quad 10.1128 /$ AEM.00062-07.

573 Wang F, Chen S, Wang Y, Zhang Y, Hu C, Liu B. 2018. Long-term nitrogen fertilization elevates the activity 574 and abundance of nitrifying and denitrifying microbial communities in an upland soil: implications for 575 nitrogen loss from intensive agricultural systems. Frontiers in Microbiology 9:2424 DOI $576 \quad 10.3389 /$ fmicb.2018.02424.

577 Wang Z, Liu Y, Zhao L, Zhang W, Liu L. 2019. Change of soil microbial community under long-term 578 fertilization in a reclaimed sandy agricultural ecosystem. PeerJ 7:e6497 DOI 10.7717/peerj.6497.

579 Watanabe A, Ikeya K, Kanazaki N, Makabe S, Sugiura Y, Shibata A. 2014. Five crop seasons' records of 580 greenhouse gas fluxes from upland fields with repetitive applications of biochar and cattle manure. Journal 581 of Environmental Management 144:168-175 DOI 10.1016/j.jenvman.2014.05.032.

582 Yin C, Fan F, Song A, Cui P, Li T, Liang Y. 2015. Denitrification potential under different fertilization regimes 583 is closely coupled with changes in the denitrifying community in a black soil. Applied Microbiology \& 584 Biotechnology 99:5719-5729 DOI 10.1007/s00253-015-6461-0.

585 Zhang J, Kobert K, Flouri T, Stamatakis A. 2014. PEAR: a fast and accurate Illumina Paired-End reAd mergeR. 586 Bioinformatics 30(5):614-620 DOI 10.1093/bioinformatics/btt593.

587 Zhang Y, Shen H, He X, Thomas BW, Lupwayi NZ, Hao X, Thomas MC, Shi X. 2017. Fertilization shapes 588 bacterial community structure by alteration of soil pH. Frontiers in Microbiology 8:1325 DOI $589 \quad 10.3389 /$ fmicb.2017.01325.

590 Zhou M, Zhu B, Wang S, Zhu X, Vereecken H, Brüggemann N. 2017. Stimulation of $\mathrm{N}_{2} \mathrm{O}$ emission by manure 
591 application to agricultural soils may largely offset carbon benefits: a global meta-analysis. Global Change 592 Biology 23:4068-4083 DOI 10.1111/gcb.13648.

593 Zhou ZF, Zheng YM, Shen JP, Zhang LM, He JZ. 2011. Response of denitrification genes and to irrigation 594 water quality in a Chinese agricultural soil. Environmental Science \& Pollution Research 18:1644-1652 DOI 595 $10.1007 / \mathrm{s} 11356-011-0482-8$. 


\section{Table 1 (on next page)}

The primer sets and thermocycling conditions used for quantitative PCR reactions. 


\begin{tabular}{|c|c|c|c|c|c|c|}
\hline $\begin{array}{l}\text { Target } \\
\text { gene }\end{array}$ & Primer set & Sequence (5'-3') & $\begin{array}{l}\text { Product } \\
\text { size (bp) }\end{array}$ & $\begin{array}{l}\text { Annealing time } \\
\text { and temperature }\end{array}$ & $\begin{array}{l}\text { Elongation time } \\
\text { and temperature }\end{array}$ & Reference \\
\hline \multirow{4}{*}{$\begin{array}{l}\text { Archaeal } \\
\text { amoA } \\
\text { Bacterial } \\
\text { amoA }\end{array}$} & Arch-amoAF & STA ATG GTC TGG CTT AGA CG & \multirow[t]{2}{*}{635} & \multirow[t]{2}{*}{$30 \mathrm{~s}, 55^{\circ} \mathrm{C}$} & \multirow[t]{2}{*}{$30 \mathrm{~s}, 72^{\circ} \mathrm{C}$} & \multirow{4}{*}{$\begin{array}{l}\text { Francis et al. } \\
\text { (2005) } \\
\text { Rotthauwe, Witzel } \\
\text { \& Liesack (1997) }\end{array}$} \\
\hline & Arch-amoAR & GCG GCC ATC CAT CTG TAT GT & & & & \\
\hline & amoA1F & GGG GTT TCT ACT GGT GGT & \multirow[t]{2}{*}{491} & \multirow[t]{2}{*}{$30 \mathrm{~s}, 56^{\circ} \mathrm{C}$} & \multirow[t]{2}{*}{$30 \mathrm{~s}, 72^{\circ} \mathrm{C}$} & \\
\hline & $\operatorname{amoA} 2 \mathrm{R}$ & $\begin{array}{l}\text { CCC CTC KGS AAA GCC TTC } \\
\text { TTC }\end{array}$ & & & & \\
\hline \multirow[t]{2}{*}{$\operatorname{nar} G$} & narGG-F & TCGCCSATYCCGGCSATGTC & \multirow[t]{2}{*}{173} & \multirow[t]{2}{*}{$30 \mathrm{~s}, 55^{\circ} \mathrm{C}$} & \multirow[t]{2}{*}{$30 \mathrm{~s}, 72^{\circ} \mathrm{C}$} & Bru, Sarr \& \\
\hline & narGG-R & $\begin{array}{l}\text { GAGTTGTACCAGTCRGCSGAYT } \\
\text { CSG }\end{array}$ & & & & Philippot (2007) \\
\hline \multirow[t]{2}{*}{$\operatorname{nir} S$} & $\operatorname{nirS4QF}$ & GTS AAC GYS AAG GAR ACSGG & \multirow[t]{2}{*}{465} & \multirow[t]{2}{*}{$30 \mathrm{~s}, 60^{\circ} \mathrm{C}$} & \multirow[t]{2}{*}{$30 \mathrm{~s}, 72^{\circ} \mathrm{C}$} & \multirow{2}{*}{$\begin{array}{l}\text { Throback et al. } \\
\text { (2004) }\end{array}$} \\
\hline & nirS6QR & $\begin{array}{l}\text { GAS TTC GGR TGS GTC } \\
\text { TTSAYGAA }\end{array}$ & & & & \\
\hline \multirow[t]{2}{*}{$\operatorname{nirK}$} & $\mathrm{FlaCu}$ & ATCATGGTSCTGCCGCG & \multirow[t]{2}{*}{474} & \multirow[t]{2}{*}{$30 \mathrm{~s}, 63^{\circ} \mathrm{C}$} & \multirow[t]{2}{*}{$30 \mathrm{~s}, 72^{\circ} \mathrm{C}$} & \multirow{4}{*}{$\begin{array}{l}\text { Throback et al. } \\
\text { (2004) } \\
\text { Scala \& Kerkhof } \\
\text { (1998) }\end{array}$} \\
\hline & $\mathrm{R} 3 \mathrm{Cu}$ & GCCTCGATCAGRTTGTGGTT & & & & \\
\hline \multirow[t]{2}{*}{$n o s Z$} & nosZF & CGYTGTTCMTCGACAGCCG & \multirow[t]{2}{*}{453} & \multirow[t]{2}{*}{$30 \mathrm{~s}, 61^{\circ} \mathrm{C}$} & \multirow[t]{2}{*}{$35 \mathrm{~s}, 72^{\circ} \mathrm{C}$} & \\
\hline & nosZ-1622R & CGSACCTTSTTGCCSTYGCG & & & & \\
\hline
\end{tabular}




\section{Table 2 (on next page)}

Soil $(0-20 \mathrm{~cm})$ properties following addition of treatments in the drip-irrigated cotton field used in this study. U+M: $50 \%$ urea $+50 \%$ manure. Values are the mean \pm 1 standard error, $\mathrm{n}=4$. 


\begin{tabular}{|c|c|c|c|c|c|c|}
\hline Treatment & $\begin{array}{l}\text { Total } N \\
\text { content }\left(\mathrm{g} \mathrm{kg}^{-1}\right)\end{array}$ & $\begin{array}{l}\mathrm{NO}_{3}^{-} \\
\left(\mathrm{mg} \mathrm{kg}^{-1}\right) \\
\end{array}$ & $\begin{array}{l}\mathrm{NH}_{4}^{+} \\
\left(\mathrm{mg} \mathrm{kg}^{-1}\right) \\
\end{array}$ & $\begin{array}{l}\text { Total C } \\
\text { content }\left(\mathrm{g} \mathrm{kg}^{-1}\right)\end{array}$ & $\begin{array}{l}\text { DOC } \\
\left(\mathrm{mg} \mathrm{g}^{-1}\right)\end{array}$ & $\mathrm{C}: \mathrm{N}$ \\
\hline Control & $0.9 \pm 0.1 \mathrm{c}$ & $21 \pm 3 \mathrm{~b}$ & $14.1 \pm 0.1 \mathrm{a}$ & $7.8 \pm 0.5 \mathrm{~b}$ & $0.21 \pm 0.01 \mathrm{~b}$ & $9.2 \pm 0.7 \mathrm{bc}$ \\
\hline Urea & $1.0 \pm 0.2 \mathrm{bc}$ & $30 \pm 2 \mathrm{~b}$ & $17.9 \pm 3.2 \mathrm{a}$ & $6.8 \pm 0.4 \mathrm{~b}$ & $0.20 \pm 0.02 \mathrm{~b}$ & $6.8 \pm 1.3 \mathrm{c}$ \\
\hline Manure & $1.3 \pm 0.1 \mathrm{ab}$ & $120 \pm 29 \mathrm{a}$ & $15.4 \pm 1.5 \mathrm{a}$ & $15.9 \pm 1.4 \mathrm{a}$ & $0.37 \pm 0.04 \mathrm{a}$ & $12.6 \pm 0.8 \mathrm{ab}$ \\
\hline $\mathrm{U}+\mathrm{M}$ & $1.4 \pm 0.1 \mathrm{a}$ & $103 \pm 7 \mathrm{a}$ & $17.9 \pm 2.6 \mathrm{a}$ & $19.1 \pm 1.8 \mathrm{a}$ & $0.36 \pm 0.02 \mathrm{a}$ & $13.6 \pm 1.3 \mathrm{a}$ \\
\hline
\end{tabular}

2 Means within a column followed by the same letter are not significantly different at $P<0.05$ (Tukey's HSD). 


\section{Table 3 (on next page)}

Diversity of the microbial community at a similarity level of $97 \%$ for operational taxonomic units (OUT) as affected by addition of treatments in the drip-irrigated cotton field used in this study. Values are means \pm 1 standard error, $n=3$ (For each treat 
Table 3 Diversity of the microbial community at a similarity level of $97 \%$ for operational taxonomic units (OUT) as affected by addition of treatments in the drip-irrigated cotton field used in this study. Values are means \pm 1 standard error, $n=3$ (For each treatment, soils from three replicated plots were sampled for high-throughput sequencing analysis).

\begin{tabular}{llllllll} 
Treatment & Coverage index & Reads & OTUs & Shannon & ACE & Chao1 & Simpson \\
\hline Control & $0.93 \pm 0.00 \mathrm{a}$ & $27,131 \pm 854 \mathrm{a}$ & $4,353 \pm 100 \mathrm{a}$ & $7.0 \pm 0.12 \mathrm{a}$ & $7,001 \pm 662 \mathrm{a}$ & $6,354 \pm 240 \mathrm{a}$ & $0.0070 \pm 0.0023 \mathrm{a}$ \\
Urea & $0.94 \pm 0.00 \mathrm{a}$ & $28,812 \pm 63 \mathrm{a}$ & $4,395 \pm 70 \mathrm{a}$ & $6.9 \pm 0.07 \mathrm{a}$ & $7,001 \pm 385 \mathrm{a}$ & $6,429 \pm 63 \mathrm{a}$ & $0.0068 \pm 0.0011 \mathrm{a}$ \\
Manure & $0.94 \pm 0.01 \mathrm{a}$ & $26,413 \pm 2,397 \mathrm{a}$ & $4,072 \pm 164 \mathrm{a}$ & $7.1 \pm 0.04 \mathrm{a}$ & $6,106 \pm 147 \mathrm{a}$ & $5,972 \pm 151 \mathrm{a}$ & $0.0031 \pm 0.0002 \mathrm{a}$ \\
$\mathrm{U}+\mathrm{M}$ & $0.94 \pm 0.00 \mathrm{a}$ & $30,405 \pm 1,280 \mathrm{a}$ & $4,291 \pm 171 \mathrm{a}$ & $7.1 \pm 0.07 \mathrm{a}$ & $6,413 \pm 262 \mathrm{a}$ & $6,323 \pm 278 \mathrm{a}$ & $0.0031 \pm 0.0004 \mathrm{a}$ \\
\hline
\end{tabular}

2 Means within a column followed by the same letter are not significantly different at $P<0.05$ (Tukey's HSD). 


\section{Table 4 (on next page)}

Relative abundances (\%) of selected bacterial and archaeal taxa at the phyla level as affected by addition of treatments to soil in this study. 


\begin{tabular}{|c|c|c|c|c|c|c|c|c|c|c|c|}
\hline & & & & & Bacteria & & & & & Arch & aea \\
\hline & $\begin{array}{l}\text { Proteobac } \\
\text { teria }\end{array}$ & $\begin{array}{l}\text { Planctomy } \\
\text { cetes }\end{array}$ & $\begin{array}{l}\text { Acidob } \\
\text { acteria }\end{array}$ & $\begin{array}{l}\text { Actinoba } \\
\text { cteria }\end{array}$ & $\begin{array}{l}\text { Bactero } \\
\text { idetes }\end{array}$ & $\begin{array}{l}\text { Armatim } \\
\text { onadetes }\end{array}$ & $\begin{array}{l}\text { Ignaviba } \\
\text { cteriae }\end{array}$ & $\begin{array}{l}\text { candidate } \\
\text { division } \\
\text { WPS-2 }\end{array}$ & $\begin{array}{l}\text { Latescib } \\
\text { acteria }\end{array}$ & $\begin{array}{l}\text { Thaumar } \\
\text { chaeota }\end{array}$ & $\begin{array}{l}\text { Euryarc } \\
\text { haeota }\end{array}$ \\
\hline Control & $32.5 \mathrm{a}$ & $8.9 \mathrm{~b}$ & $11.5 \mathrm{a}$ & $11.6 \mathrm{a}$ & $5.6 \mathrm{~b}$ & $0.62 \mathrm{a}$ & $0.13 \mathrm{~b}$ & $0.07 \mathrm{a}$ & $0.12 \mathrm{a}$ & $0.58 \mathrm{a}$ & $0.77 \mathrm{a}$ \\
\hline Urea & $32.2 \mathrm{a}$ & $8.3 \mathrm{~b}$ & $10.7 \mathrm{a}$ & $12.1 \mathrm{a}$ & $6.2 \mathrm{~b}$ & $0.67 \mathrm{a}$ & $0.14 \mathrm{~b}$ & $0.04 \mathrm{a}$ & $0.08 \mathrm{ab}$ & $0.50 \mathrm{ab}$ & $0.87 \mathrm{a}$ \\
\hline Manure & $34.6 \mathrm{a}$ & $11.1 \mathrm{a}$ & $8.8 \mathrm{~b}$ & $9.0 \mathrm{~b}$ & $11.4 \mathrm{a}$ & $0.37 \mathrm{~b}$ & $0.25 \mathrm{a}$ & $0.01 \mathrm{~b}$ & $0.06 \mathrm{~b}$ & $0.24 \mathrm{bc}$ & $0.24 \mathrm{~b}$ \\
\hline $\mathrm{U}+\mathrm{M}$ & $35.1 \mathrm{a}$ & $10.0 \mathrm{a}$ & $7.5 \mathrm{~b}$ & $9.4 \mathrm{~b}$ & $8.3 \mathrm{ab}$ & $0.27 \mathrm{~b}$ & $0.20 \mathrm{ab}$ & $0.01 \mathrm{~b}$ & $0.04 \mathrm{~b}$ & $0.30 \mathrm{~b}$ & $0.24 \mathrm{~b}$ \\
\hline
\end{tabular}

2 Means followed by the same letter are not significantly different at $P<0.05$ (Tukey's HSD). 


\section{Table 5 (on next page)}

Pearson correlation coefficients $(r)$ between copy number of $\mathrm{N}_{2} \mathrm{O}$-related functional genes and soil characteristics across all treatments and replicates, $n=16$. 


\begin{tabular}{|c|c|c|c|c|c|c|}
\hline & $A O A$ & $A O B$ & narG & $\operatorname{nos} Z$ & nirS & nirK \\
\hline $\mathrm{NO}_{3}^{-}\left(\mathrm{mg} \mathrm{kg}^{-1}\right)$ & $0.65 * *$ & $0.61 *$ & $0.81 * * *$ & $0.65 * *$ & 0.24 & $0.77 * * *$ \\
\hline $\mathrm{NH}_{4}^{+}\left(\mathrm{mg} \mathrm{kg}^{-1}\right)$ & -0.29 & 0.15 & -0.58 & -0.14 & -0.24 & 0.01 \\
\hline $\mathrm{DOC}\left(\mathrm{mg} \mathrm{g}^{-1}\right)$ & $0.70 * * *$ & $0.73 * * *$ & $0.86 * * *$ & $0.76 * * *$ & 0.47 & $0.73 * * *$ \\
\hline $\mathrm{pH}$ & -0.22 & -0.30 & -0.40 & -0.25 & -0.28 & -0.33 \\
\hline $\mathrm{TN}\left(\mathrm{g} \mathrm{kg}^{-1}\right)$ & $0.63 *$ & $0.71 * *$ & $0.66^{* *}$ & $0.58 * *$ & 0.21 & $0.63 * *$ \\
\hline $\mathrm{TC}\left(\mathrm{g} \mathrm{kg}^{-1}\right)$ & $0.85 * * *$ & $0.82 * * *$ & $0.82 * * *$ & $0.72 * *$ & 0.31 & $0.76 * * *$ \\
\hline $\mathrm{C} / \mathrm{N}$ & $0.72 * *$ & $0.61 *$ & $0.67 * *$ & $0.58 *$ & 0.29 & $0.62 * *$ \\
\hline DEA (ug $\left.\mathrm{N}_{2} \mathrm{O}-\mathrm{N} \mathrm{g}^{-1} \mathrm{~h}^{-1}\right)$ & $0.57 *$ & $0.85 * * *$ & $0.84 * * *$ & $0.70 * *$ & 0.31 & $0.76^{* * *}$ \\
\hline $\mathrm{NEA}\left(\mathrm{ug} \mathrm{N}-\mathrm{NO}_{2}^{-}+\mathrm{NO}_{3}^{-} \mathrm{g}^{-1} \mathrm{~h}^{-1}\right)$ & 0.19 & 0.26 & 0.18 & 0.06 & -0.22 & $0.64 * *$ \\
\hline
\end{tabular}

$2 *, * *, * * *$ indicate significance at $P<0.05,<0.01$ and $<0.001$, respectively. 


\section{Figure 1}

Denitrifying enzyme activity (DEA) and nitrifying enzyme activity (NEA) as affected by addition treatments in soil of the drip-irrigated cotton field used in this study. U+M: $50 \%$ urea $+50 \%$ manure. Data are means +1 standard error, $n=4$. Means followed by

Figure 1 Denitrifying enzyme activity (DEA) and nitrifying enzyme activity (NEA) as affected by addition treatments in soil of the drip-irrigated cotton field used in this study. U+M: $50 \%$ urea $+50 \%$ manure. Data are means +1 standard error, $n=4$. Means followed by the same letter are not significantly different at $P<0.05$ (Tukey's HSD). 

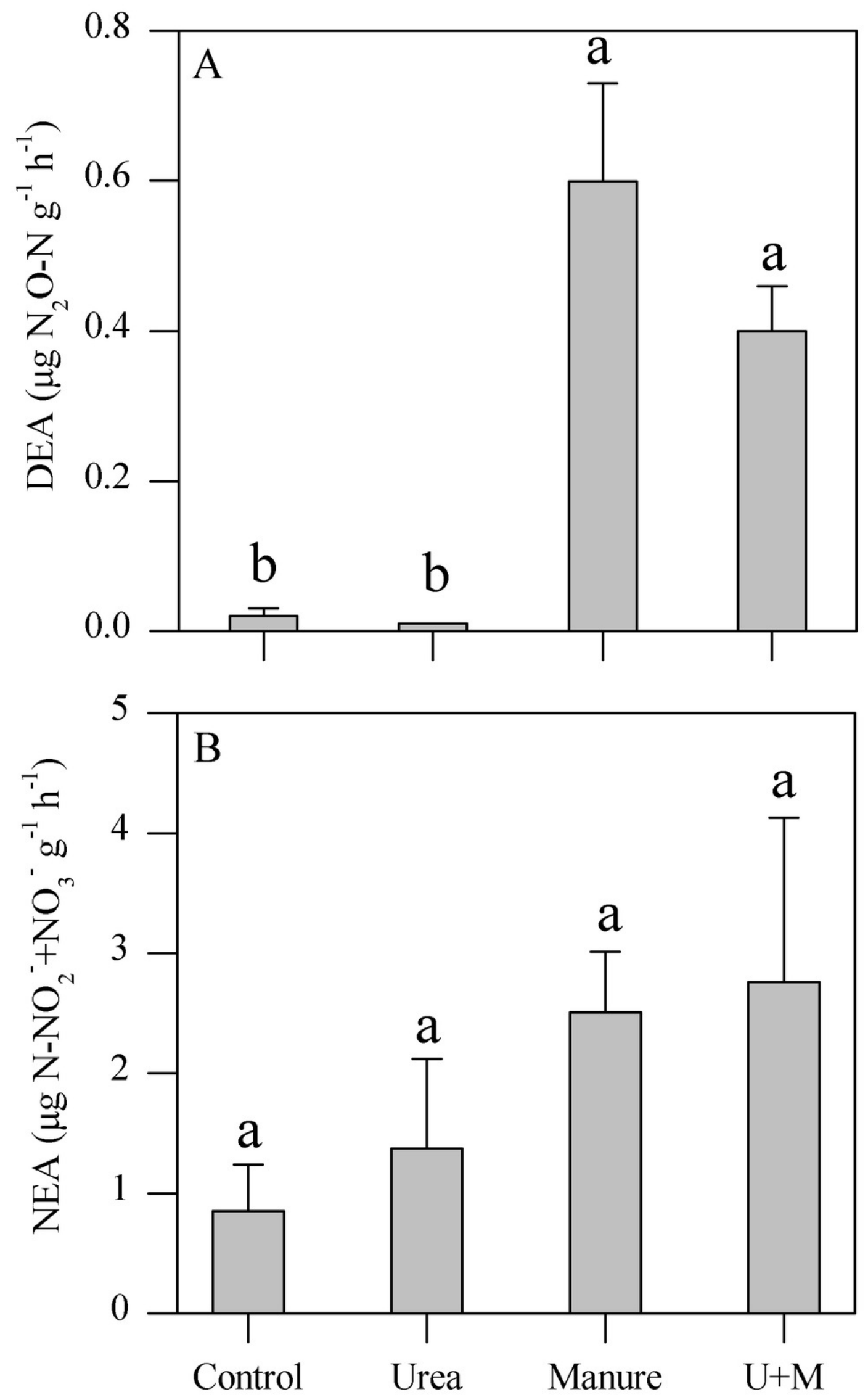


\section{Figure 2}

Principal Coordinates Analysis (PCOA) plot of weighted Unifrac distance matrix showing patterns of $\beta$-diversity in microbial communities as affected by the addition treatments to soil of the drip-irrigated cotton field used in this study. U+M: $50 \%$ urea +5

Figure 2 Principal Coordinates Analysis (PCOA) plot of weighted Unifrac distance matrix showing patterns of $\beta$-diversity in microbial communities as affected by the addition treatments to soil of the drip-irrigated cotton field used in this study. $U+M: 50 \%$ urea $+50 \%$ manure. 


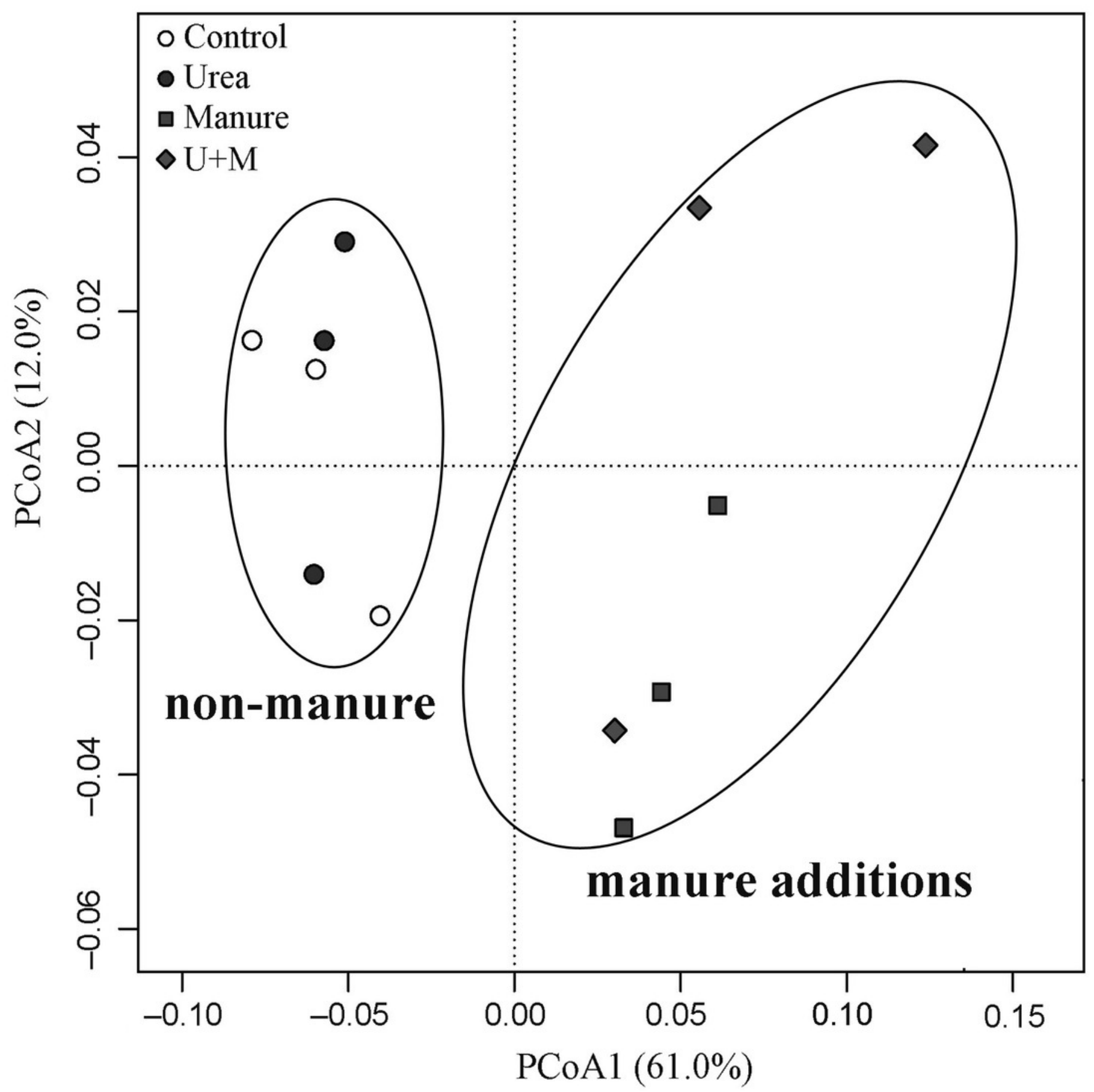




\section{Figure 3}

Copy numbers of archaeal ( $A O A$ ) and bacterial (AOB) amoA (A), nirs (B), narG (C), nosZ (D) and nirK (E) genes in soil as affected by the addition of treatments to plots in the drip-irrigated cotton field used in th

Figure 3 Copy numbers of archaeal (AOA) and bacterial (AOB) amoA (A), nirs (B), narG (C), nosZ (D) and nirK (E) genes in soil as affected by the addition of treatments to plots in the drip-irrigated cotton field used in this study. Data are means +1 standard error, $\mathrm{n}=4$. Means followed by the same letter are not significantly different at $P<0.05$ (Tukey's HSD). 

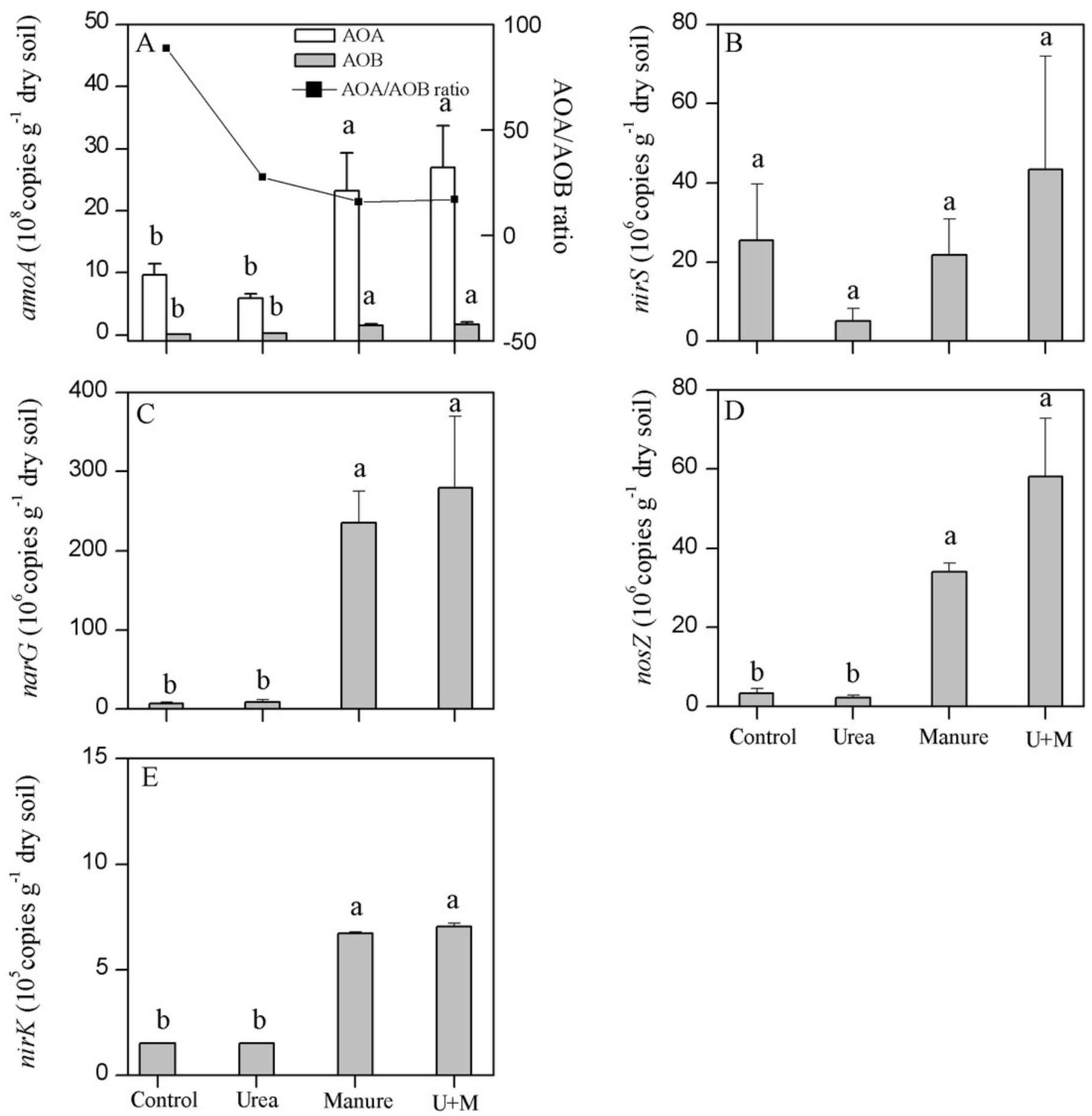
Figure 4

Canonical correspondence analysis (CCA) bi-plot of soil properties in relation to microbial OTUs as affected by the addition of treatments to soil of the drip-irrigated cotton field used in this study.

Figure 4 Canonical correspondence analysis (CCA) bi-plot of soil properties in relation to microbial OTUs as affected by the addition of treatments to soil of the drip-irrigated cotton field used in this study. 


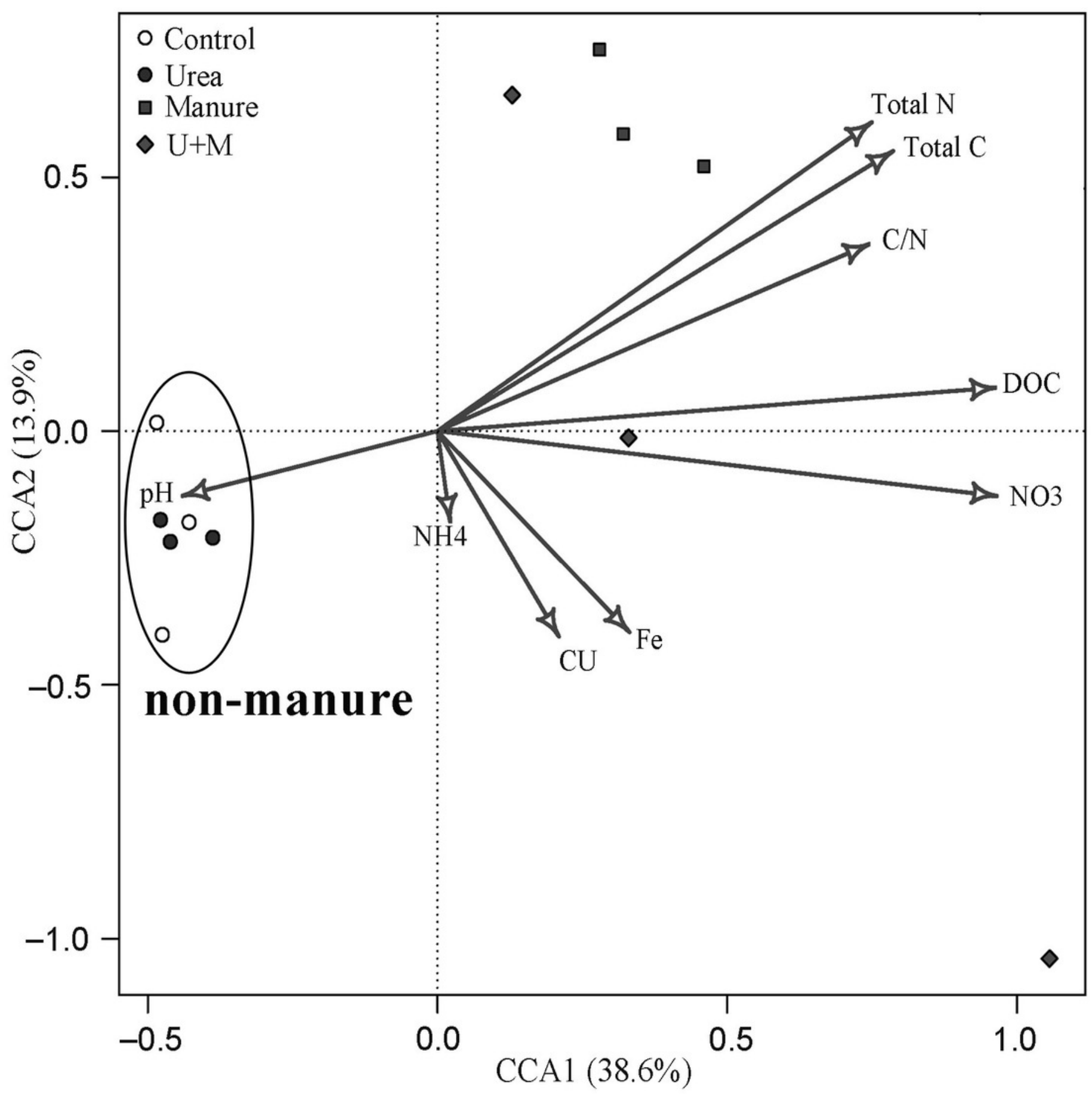

